\title{
An exploratory study of information-giving used to promote chlamydial test-seeking by students at a college family planning clinic
}

Hugo McClean, MRCPI, DFFP, Consultant in Sexual Health Medicine, Lansdowne Clinic, Hull and East Yorkshire Hospitals NHS
Trust, Hull, UK.

Jem Sutherland BA (Hons), Peer Group Worker, AIDS Action, Cornerhouse, Hull, UK

Stella Searle MFFP, MIPM, Lead Senior Clinical Medical Officer, Sexual and Reproductive Health Services, Hull and East Riding Community NHS Trust, Victoria House, Hull, UK.

Pat Howarth RGN, Dip Coun, Health Adviser, Department of Genitourinary Medicine, Castle Hill Hospital, Hull and East Yorkshire NHS Trust, Cottingham, UK

Correspondence: Hugo McClean, Consultant in Sexual Health Medicine, Lansdowne Clinic, Hull and East Yorkshire Hospitals NHS Trust, Hull, HU3 2JZ.

(Accepted July $\left.12^{\text {th }}, 2000\right)$

\begin{abstract}
Summary
Partnership working, involving workers in various aspects of sexual health and a large UK further education college, took place to give information about genital tract chlamydial infection in order to promote chlamydial urine testing ( $L C_{x}$ Chlamydia trachomatis Assay Abbott Diagnosis Division) for a limited period at the college's family planning clinic. Female students were more likely to report awareness about the availability of testing and to access the testing service. Uptake of testing was largely contemporaneous with information-giving work and sharply declined after information-giving had ceased. A small population of test seekers (including partners of index cases) was generated, which harvested a rate of genital tract chlamydial infection similar to that found in family planning and genitourinary medicine clinics.
\end{abstract}

\section{Key words}

attitude to health, Chlamydia trachomatis, patient education, preventative health services

\section{Key message points \\ - Information-giving, supported by partnerships between sexual health workers and a large UK further education college, can promote uptake of genital chlamydial testing by students at a college family planning clinic. \\ - More work is needed to determine the role of partnership working between Sexual Health and Education as part of developing strategies for genital chlamydial screening.}

\section{Introduction}

The case for lower genital tract chlamydial screening has been made, although more information is required to aid decision-making in setting up efficient, local screening systems. ${ }^{1}$ Partnership working between health care systems (as well as non-health organisations) and schools is being promoted as part of modern National Health Service ideology, ${ }^{2}$ although there are few published reports of developing links between sexual health services and local schools in the UK.

Although currently more expensive than other routinely used detection techniques, molecular biological techniques for the detection and amplification of chlamydial nucleic acid offer potential as a non-invasive tool for wider and more acceptable chlamydial screening. The ligase chain reaction, in particular, has been shown to be a highly sensitive and specific test for detection in urine of chlamydial nucleic acid in both women and men. ${ }^{3,4}$

\section{Background}

Hull College (including its sister sites) is one of the larger further education colleges in the UK and has a total student population of 35000 , including 3000 full time students, and most of these are younger than 25 years. A family planning clinic (FPC) was established within the main college building in 1996. The clinic takes place once weekly during $11 \mathrm{am}$ - $1 \mathrm{pm}$ on Monday mornings, and had 549 patient attendances during 1998/99.

\section{Aim}

The aim of the study (known as the Hull College Project) was to explore the effect of information-giving within the college in an attempt to encourage students to use the college's FPC as a screening site for chlamydial urine testing (CUT) for a limited period.

\section{Method}

Partnership building with college staff

Preparative discussions took place with the college administration, including a student counsellor and student representatives, as well as with a representative college tutor. One of the student counsellors was key in providing access to college staff and arranged for one of the genitourinary medicine (GUM) investigators to give a presentation on genital chlamydial infection (GCI) to a small group of tutors in January 1999 (this offer was taken-up only by female tutors). The student counsellor also liaised with tutors to allow access to their tutorial groups by information-givers from a local voluntary agency involved in sexual health.

\section{Information-giving}

The information-givers comprised a peer group worker and volunteers trained by the peer-group worker. Various information-giving strategies were used:

- Initial information-giving was delivered by two information-givers (one manning a stall and the other 
circulating, actively engaging students in discussion about GCI and the project) at the beginning of the academic year during Fresher's week in September (daily for 4 hours during 5 days), and again during the College Health Fair in October 1998 (1 day).

- The information-givers delivered 14 further information-giving inputs, lasting 15 to 20 minutes each, during previously established health and development tutorials (including one tutorial at one of the sister colleges) during January, February and March of 1999. Information-giving about GCI included mode of transmission, natural history and treatment, as well as the availability of CUT at the college FPC.

- Information about the project was published in the students' newsletter prior to the start of the project.

- Posters advertising the chlamydial test, along with information about treatment, were also displayed in busy areas within the college building.

- After nine tutorial information-giving inputs, volunteers on the main college building forecourt obtained the anonymous responses from students about the following: gender, awareness about GCI, awareness of availability of CUT at the college FPC and views about the project.

Confidentiality was emphasised throughout as an important aspect of the urine-testing service.

\section{Chlamydial testing}

CUT was available at the college FPC during February to May 1999. On presentation to the FPC for CUT, test-seekers were directed to the additional resource of one of the GUM investigators. During a 5-10 minute interview, further information-giving focused on GCI was provided, and demographic information as well as the source of information about the project obtained. Written consent was obtained.

Choices were offered about accessing results of the tests (returning to the clinic, telephoning the clinic or being contacted by the clinic). Students were provided with plastic containers for return of urine specimens before the end of that day's clinic. The urine specimens were posted to a laboratory testing site for detection of Chlamydia trachomatis by ligase chain reaction amplification technology (LCx Chlamydia trachomatis Assay Abbott Diagnostics Division). Results were returned by post to the FPC in time for the next week's clinic. Anti-chlamydial antibiotics (doxycycline, erythromycin and azithromycin) were available, and supporting written information was provided at the FPC. All students with positive results were managed by the GUM investigators, including partner notification work at the FPC or the local GUM clinic.

The chi-squared test was used to compare categorical data where appropriate.

Approval of the project was obtained by prior application to the Local Ethics Committee.

\section{Results}

Results of awareness survey

Five interviewers interviewed 149 students. Female students were more likely than male students to be interviewed: $88(59.1 \%)$ versus $58(38.9 \%)$, respectively, $(\mathrm{p}<0.05)$; gender was not specified for three $(2 \%)$ interviewees. Female students were more likely to report positive responses with regard to awareness of GCI and availability of CUT at the College FPC (see Table 1). Seventy-six (51\%) students reported awareness about Chlamydia and these were mostly female students; the majority of students $(47,61.8 \%)$ had found out about Chlamydia through the project (see Table 2). Female students were also more likely to report a positive response to the Project (see Table 3).

Information-giving during Fresher's week and the College Health Fair

Ninety female and 31 male students were accessed during these events during an estimated time of 23 hours.

\section{Information-giving during tutorials}

Access to students during tutorial times was relatively more efficient than other means of access, with 408 female students and 68 male students accessed during an estimated 5 hours of information-giving. Of the 14 tutorial groups accessed, nine were female-only, two were male-only and three were mixed sex.

\section{Use of CUT service}

Forty-six students, 44 (95.6\%) female and two (4.3\%) male students, presented to the FPC requesting CUT; of these five $(11 \%)$ were aged 16, $23(50 \%)$ aged 17, three $(6.5 \%)$ aged 18 , one $(2 \%)$ aged 19 , three $(6.5 \%)$ aged 20 and 11 $(24 \%)$ were aged more than 20 years. Test-seeking was closely related to the occurrence of direct informationgiving during tutorials, with most students $(42,91 \%)$ requesting testing during, or within 10 days of the completion of information-giving. The remaining four tests were sought during six clinics which continued to offer testing beyond this period.

Only six $(13 \%)$ students requesting CUT were routine attendees at the FPC. The most common source of information about the availability of CUT was from information-giving during tutorial time, with 42(91\%) reporting this as a source of information about availability of the test. Twenty-six (56.5\%), 15 (32.6\%) and two (4.3\%) also reported posters, word of mouth and information from partners, respectively, as a source of information about the project. Forty-four students $(95.6 \%)$ returned the urine specimen bottle. Of these, three $(6.8 \%)$ tests were positive and one $(2.3 \%)$ specimen gave rise to an equivocal result; all of these results were from non-routine clinic attendees.

Table 1 Awareness of genital tract chlamydial infection and availability of urine test for chlamydial detection

\begin{tabular}{|c|c|c|c|c|c|}
\hline & Yes $(\%)$ & No $(\%)$ & No response $(\%)$ & Total $(\%)$ & $\mathrm{p}$ value \\
\hline \multicolumn{6}{|c|}{ Chlamydia awareness } \\
\hline Male & $19(32.8)$ & $39(67.2)$ & $0(0)$ & $58(100)$ & $<0.05$ \\
\hline Female & $57(64.8)$ & $31(35.2)$ & $0(0)$ & $88(100)$ & $\chi^{2}=4.36, \mathrm{df}=1$ \\
\hline Total & $76 *(51)$ & $73(49)$ & $0(0)$ & $149(100)$ & \\
\hline \multicolumn{6}{|c|}{ Urine testing awareness } \\
\hline Male & $5(8.6)$ & $48(82.8)$ & $5(8.6)$ & $58(100)$ & $<0.05$ \\
\hline Female & $51(58.0)$ & $36(40.9)$ & $1(1.1)$ & $88(100)$ & $\chi^{2}=37.59, \mathrm{df}=2$ \\
\hline \multirow[t]{2}{*}{ Total } & $56(37.6)$ & $87(58.4)$ & $6(4)$ & & \\
\hline & 149 (100) & & & & \\
\hline
\end{tabular}


Table 2 Source of information about Chlamydia

\begin{tabular}{lcccl}
\hline & Male (\%) & Female $(\%)$ & Total $(\%)$ & p value \\
\hline Project & $8(10.5)$ & $39(51.3)$ & $47(61.8)$ & $<0.1$ \\
Outside project & $8(10.5)$ & $16(21.1)$ & $24(31.6)$ & $\chi^{2}=5.75, \mathrm{df}=2$ \\
No response & $3(4.0)$ & $2(2.6)$ & $5(6.6)$ & \\
Total & $19(25.0)$ & $57(75.0)$ & $76(100)$ & \\
\hline
\end{tabular}

Table 3 Response of students to the project being carried out

\begin{tabular}{lcccl}
\hline & Male $(\%)$ & Female $(\%)$ & Total $(\%)$ & p value \\
\hline Good idea & $18(31.0)$ & $59(67)$ & $79(53)$ & $<0.05$ \\
Bad idea & $1(1.7)$ & $3(3.4)$ & $4(2.7)$ & $\chi^{2}=17.35, \mathrm{df}=3$ \\
Neutral & $11(19)$ & $16(18.2)$ & $27(18.1)$ & \\
No response & $28(48.3)$ & $10(11.4)$ & $39(26.2)$ & \\
Total & $58(100)$ & $88(100)$ & $149(100)$ & \\
\hline
\end{tabular}

Twenty-four (52.2\%) students chose to leave contact details with the investigators. Test results were accessed by $28(63.6 \%)$ students. For those who accessed results, 11 $(39.3 \%)$ accessed the result during the following week's clinic, nine $(32.1 \%)$ in 2 week's time, and eight $(28.6 \%)$ during the third or later clinic after testing. Twenty-one $(77.8 \%)$ students accessed their results by returning to the FPC and six $(22.2 \%)$ by telephoning the FPC.

\section{Follow-up and partner notification}

One of the students with a positive result, and the student with the equivocal result, were contacted (with permission) by one of the GUM investigators. Both of these were followed-up at the local GUM clinic, but both declined genital examination and further infection screening. Both were interviewed by the health adviser and a total of five traceable contacts (for the previous 6 months) were identified, one of whom (with a negative result for chlamydial antigen detection) later attended the clinic.

The other two positives, who contacted the FPC themselves, were followed-up at the FPC where further screening was not available. Partner notification work with each lead to both of their traceable contacts (for the previous 6 months), both with positive results for chlamydial antigen detection, being seen at the local GUM clinic.

All of the index cases, including the student with the equivocal test result, received treatment with doxycycline. All partners seen received epidemiological treatment.

Thus the Project harvested a total of five positive test results and one equivocal test result.

\section{Discussion}

This, albeit small study, provides some evidence that partnership working between a college and various workers involved in sexual health to promote CUT, merits further investigation. The only additional funding obtained for this study was for the CUT. The funding which would have been required to support the information-givers or the additional resources at the FPC was not quantified. The abrupt fall-off in test-seeking after information-giving ceased suggests that increased test-seeking may have occurred had more information-giving been possible. However, a relatively limited information-giving input accessed a large number of students, and resulted in a small population of test-seekers with rates of chlamydial infection comparable to that obtained in routine FPC $^{5}$ and GUM clinic ${ }^{6}$ attendees.

This study suggests that regular information-giving inputs are more likely to result in test-seeking behaviour, although the effect of this is not sustained. Additionally, direct contact with information-givers in the setting of tutorial groups was the most effective form of motivation towards test-seeking. (Anecdotally, the investigators formed the impression that personality of the informationgivers contributed to this, since this was mentioned en passant by many of the students seeking tests.)

Young women are generally more likely to access a variety of health care services, ${ }^{7}$ although the female preponderance in both information-uptake about the project and use of the testing service may have reflected bias from tutors in influencing access to their student groups. In contrast to tutorial groups of mainly female students (taught by female tutors), the student counsellor reported failure of several attempts (by telephoning and writing) made by her to provide access by the information-givers to mainly male tutorial groups (taught by male tutors). However, this difference may also have to do with the main female groups of students (School of Development, Education and Child Studies and School of Hairdressing and Beauty Therapy) already having a tradition of being taught female health at the college.

This study did not incorporate a specific mechanism to monitor any additional test-seeking at sites distant from the college FPC, although this level of information management support might usefully be developed as part of future partnership working.

GUM clinics are the sites most frequently associated with chlamydial screening although, paradoxically, it is likely that GUM clinics manage less than $10 \%$ of the total community prevalence of GCI. ${ }^{8}$ This suggests that a broad base of whole-community genital chlamydial screening should be developed. Various methods may provide models for access to young people of chlamydial screening. For example, one medical-based, collaborative project ${ }^{9}$ at a community teenage clinic, involving various workers in sexual health, harvested a high positivity rate of GCI by offering selective screening to teenage women, and produced a treatment rate of male partners well above the minimum recommended for GUM clinics. ${ }^{10}$ Alternatively, school-based sex education that is young-people centred and delivered by innovative, collaborative working between Health and Education has produced positive sexual health outcome measures, including increased knowledge about sexually transmitted infections. ${ }^{11}$ Particular strategies are likely to be locality-dependent, but further exploration of partnership working between sexual health providers and colleges or schools, including cost-effectiveness work, may be important in some areas.

\section{Acknowledgements}

Thanks to Jan Fairfax (Student Counsellor, Hull College), Christine Upton (Assistant Principal, Hull College), Alan Battley (Tutor, Hull College) and Alison Bates and Nick Lumb, (student representatives, Hull College) for support and advice. The advice and support of Alan Smith of Abbott Diagnostics, as well as Gordon Laboratory Group, Stockton-On-Tees, who carried out the assays, is also gratefully acknowledged.

Statements on funding and competing interests

Funding. Funding for the LCx Chlamydia trachomatis Assay was provided by Abbott Diagnostics Division.

Competing interests. None.

1 Boag F, Kelly F. Screening for Chlamydia trachomatis. BMJ 1998; 316: 1479. Dobson F, Jowell T. Our Healthier Nation: a contract for health (Cm3852). London: HMSO, Lee H.

Lee HH, Chernesky MA, Schachter J, et al. Diagnosis of Chlamydia trachomatis genitourinary infection in women by ligase chain reaction of urine. Lancet 1995; 345: 213-216.

Chernesky MA, Lee H, Schachter J, et al. Diagnosis of Chlamydia trachomatis urethra infection in symptomatic and asymptomatic men by testing first-void urine in a ligase chain reaction assay. J Infect Dis 1994; 170: 1308-311.

Stokes T. Chlamydia infection in UK family planning clinics. Br J Fam Plann 1997; 23 $47-50$

6 PHLS. Sexually transmitted diseases quarterly report: genital infection with Chlamydia trachomatis in England and Wales. Commun Dis Rep CDR Wkly 1997; 7: 394-395. 
7 Chief Medical Officer - Main report of the Chief Medical Officer's Expert Advisory Group Chlamydia trachomatis. London: Department of Health, 1998.

Simms I, Catchpole M, Brugha R, et al. Epidemiology of genital Chlamydia trachomatis in England and Wales. Genitourin Med 1997; 73: 122-126.

9 James NJ, Hughes S, Ahmed-Jushuf, et al. A collaborative approach to management of chlamydial infection among teenagers seeking contraceptive care in a community setting. Sex Transm Infect 1999; 75: 156-161.
10 FitzGerald MR, Welch J, Robinson AJ, et al. Clinical guidelines and standards for the infection. Central Audit Group in Genitourinary Medicine. Int J STD AIDS 1998; 9: 253-262.

11 Mellanby AR, Phelps FA, Crichton NJ, et al. School sex education: an experimental programme with educational and medical benefit. BMJ 1995; 311: 414-417. 